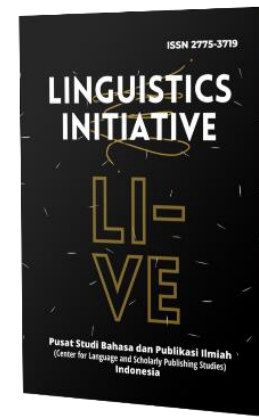

\author{
Linguistics Initiative \\ ISSN 2775-3719 \\ Volume 1, Number 1, (2021) \\ https://doi.org/10.53696/27753719.21 \\ Published by Pusat Studi Bahasa dan Publikasi Ilmiah \\ (Center for Language and Scholarly Publishing Studies) \\ Copyright $\odot 2021$ The author(s) \\ Article License: CC BY-NC 4.0
}

\title{
Questioning Strategies Applied by Lecturers in EFL Class
}

\author{
Rizkariani Sulaiman ${ }^{(1)}$ \\ (1) Universitas Muslim Indonesia, Indonesia | rizka.sulaiman@umi.ac.id
}

\begin{abstract}
The purpose of this study is aimed at finding out the questioning strategies used by lecturers during teaching, the types of questions, and the reasons for using these questioning strategies in classroom interactions in the English Education Study Program. The sample in this study are three lecturers at the English Education Study Program, Faculty of Letters, Indonesian Muslim University. The sample is selected based on teaching experience and has obtained an Educator Certificate. Then, this study uses a descriptive qualitative approach, especially discourse/conversation analysis. Data collection is carried out in three stages, namely knowing the schedule, observing the online lectures, and interviewing. Furthermore, the data is analyzed into three stages, namely data reduction, data presentation, and drawing conclusions. Based on the description of the results and discussion, it can be concluded as follows: The questioning strategies applied by the lecturers are: (1) opening questions; (2) rhetorical questions; (3) managerial questions; (4) knowledge questions; (5) comprehension/understanding questions; (6) questions about specific information; (7) analysis questions; (8) use of pausing strategy; (9) the use of prompting strategies; (10) use of probing and prompting strategies; (11) application questions; and (12) closed questions. The purpose of the application of the questions: (1) regulate the flow/process from the beginning (apperception) to reinforcement and review at the end of the lecture; (2) provide a stimulus so that students think critically; (2) directing the student's flow of thought to focus on the discussion; (3) giving emphasis, affirmation, examples; (4) knowing the level of understanding of students in the cognitive domain from $\mathrm{C} 1, \mathrm{C} 2, \mathrm{C} 3$ and $\mathrm{C} 4$; (5) build emotional relationship with students; (6) the questions are presented using pausing, prompting and probing techniques to guide and direct students to find complete answers and equal opportunities for all students to provide responses.
\end{abstract}

\section{Keywords}

questioning strategies, EFL class, conversation analysis 


\section{Introduction}

Classroom management is an important aspect of Lecturer's competence to create an effective teaching and learning process. It focuses on the lecturer's ability to plan and deliver lecture material, and to control student behavior. Harmer (2007) states that the effectiveness of teaching and learning activities depends on how the lecturer directs, guides, inspires, facilitates and controls students to participate in learning activities. Ineffective classroom management can disrupt the teaching and learning process in the classroom. One way that can be used to direct, guide, inspire, and control student participation in learning activities is to ask or ask questions. Questioning strategies are the methods used to ask students something to achieve their teaching goals. In the teaching and learning process, lecturers need to know the students' abilities and the extent to which they understand the material being taught. Asking is a process that always occurs in a communication process, including in the learning process. Asking skills are expressions or questions spoken by lecturers as stimuli to elicit responses from students (Cotton, 1989).

For Lecturers, asking questions is a very important skill to master. Because by mastering this skill, the teacher/lecturer can create a more meaningful learning atmosphere. According to Cotton (1989), the learning process will be very boring, if the lecturer explains the material for hours without interspersed with questions, both just questions to encourage motivation, as well as analytical questions. The success of TEFL (Teaching English as a Foreign Language) in the classroom refers to the implementation of the question-and-answer strategy by the lecturer. According to Halstead \& Mclaughlin (1999), questions are one of the most important tools in guiding and expanding student learning. This can help lecturers to develop their own strategies to improve students' critical thinking. The questioning strategy used by the lecturer can encourage students to be more involved in the language learning process.

The lecturer's questioning strategy must be applied because it is one of the factors that can produce an effective teaching and learning process. Asking should be applied properly as a teaching tool. It requires knowledge of the types of questions, asking strategies, and reasons for asking questions that are applied by lecturers in the classroom. Therefore, the purpose of this study is to find out what types of questions are used by the lecturer, how the lecturer applies the questioning strategy, and the reason for the lecturer in asking.

\section{Method}

\section{Research Design}

This study applied qualitative methods, especially conversational analysis. Regarding conversational analysis (CA), Hyland \& Paltridge (2011) state that conversational analysis is the study of conversation-in-interaction and is a theoretically and methodologically distinct approach to understanding social life. 


\section{Place and Subject of the Research}

This research was conducted in the EFL class (Class of English Education Study Program) Faculty of Letters Universitas Muslim Indonesia (UMI). The research subjects were 3 (three) English Education Lecturers, Faculty of Letters, UMI. The research sample was selected with the criteria of variant of the length of teaching experience and has obtained an educator certificate.

\section{Research Instrument}

The data in this study were collected using audio recordings and interviews. Audio recordings were used to collect the lecturer's questioning strategies and the questioning strategy data was also supported by confirmation of the objectives of the questioning strategy for each research subject. Audio recordings in this study were used to obtain the types of questioning strategies applied in the EFL class.

\section{Data Collection and Analysis Technique}

Data collection was carried out in three stages, namely knowing the schedule, recording and observing the lecture process online via zoom meetings, and interviews. Furthermore, the data was analyzed into three stages, namely data reduction, data presentation, and conclusion drawing. The instruments used in data collection were a list of class observations, audio recorders, and interviews. To test the distribution of the questioning strategy, the researcher recorded data using a recorder and followed the online teaching and learning process (zoom meeting).

The recorded data was transcribed into a written transformation, then identified, selected, and classified or extracted based on the need for analysis relevant to the topic of this research. Transcription was analyzed using a question-and-answer strategy analysis. Interviews are used to confirm the purpose of the questioning strategy used by lecturers during the lecture process.

\section{Results}

Based on the results of the transcripts of the teaching and learning process recordings in the classroom for an average of five meetings, the researchers found twelve types of extract questioning strategies:

\section{Opening Questions (Starting Lecture)}

\section{Extract 1}

L1 : How do you in this morning bagaimana kabarnya pagi ini?

M : Alhamdulilah fine ayah/ Alhamdulillah fine, Sir

Analysis $\quad:$ In extract 1 , the lecturer asked about the students' condition twice "How are you in this morning?" (in English) and "bagaimana kabarnya pagi ini? (using Indonesian). This question is addressed to all students to say hello and as an opening or introduction before entering the core of the lecture. 


\section{Rhetorical Questions}

\section{Extract 2(1)}

L2 : “. . . seharusnya seorang guru itu bagaimana (?) Apa (?) seorang siswa itu bagaimana (?) guru itu harus memberikan stimulus atau rangsangan kepada siswa..."

: ". . How should a teacher be (?) What (?) what about the students (?) the teacher should give a stimulus or stimulation to students. . "

Analysis : Extract 2(1) above shows that after the lecturer explained the material, it was continued by asking some rhetorical questions using wh-questions and how. Questions posed by the lecturer actually do not require an answer. However, these questions appear to be more direct and invite students to think critically about the material that has been discussed.

\section{Manajerial Questions}

\section{Extract 3(3)}

L1 : “. . ada pertanyaan sampai disini(?), do you have any question?...”

Analysis : : In extract 3(3) the lecturer asks students to ask questions about the material at the end of the explanation if there are material points that are still unclear. At the beginning of the lecturer's question using Indonesian "ada pertanyaan sampai disini?" then there is repetition of questions using English "do you have any question?" The purpose of this question, in addition to providing opportunities for students to ask questions about material that is still unclear, indirectly this question also marks the end of the explanation of the material at the meeting and will move on to another session.

\section{Knowledge/Memory Questions}

\section{Extract 4(4)}

L1 : “. . Nah jadi penelitian tindakan kelas yang pertama saya ulangi kembali ini tentang issue identification masih ingat langkah - langkahnya di pertemuan pertama?, ada berapa langkah?"

"... So, the first class action research I repeat again is about the identification issue. Do you still remember the steps in the first meeting? How many steps are there?"

Analysis : Extract 4(4) shows that at the end of the learning activity (closing) the lecturer carries out reinforcement activities by asking questions at the knowledge level "do you remember? How many steps are there?" to determine the level of knowledge and memory of students on the material that has just been delivered. The purpose of this question is not only as reinforcement, but also as a review of the material. 


\section{Comprehension/Understanding Question}

\section{Extract 5(4)}

L1 : “. . pertama bagaimana how to formulate the research question? (wait time) Ada yang bisa?

: ". . first, how to formulate the research question? (wait time) anyone?

Analysis : In Extract 5(4) the lecturer asks using the question words "how" to formulate the research question?" to check students' understanding of the topic of discussion, namely the research question. Then at the wait time, there was no response from the students, so the lecturer continued with the question "anyone?"

\section{Asking for Specific Question to Student}

\section{Extract 6(1)}

L2 : : . . speech berpidato misalnya seperti sufri itu, apa lagi bakatnya Sufri...?

: " . . speech, for example, is like Sufri, what else is Sufri's talent. . .?

Analysis : In extract 6(1), the lecturer asked all students about specific information, namely the talent/skill of one of the students in the class. Although in this case the lecturer actually knows the facts or information being asked, so the purpose of the question is confirmation. This question is a question filler or a question to fill the gap. In addition, this type of question is used by lecturers to refresh the class situation even though the meeting is through the zoom facility and the student's condition is because the lecturer feels that he has conveyed a lot of things with a long duration. To avoid the impression of being monotonous, the lecturer asked questions as in extract 6(1).

\section{Analysis Question}

\section{Extract 7(2)}

L3 : "... alraight, nah sekarang perhatikan gambar-gambar itu dari gambar nomor 1 kira-kira apa bedanya itu bagian a, b, c kemudian nomor 2, apa juga yang membedakan antara opsi $a, b, c . n o m o r ~ 3,4$, dan 5. Bunda kasi waktu 3 menit ya. ..”

: ". . alraight, now look at the pictures from picture number 1 , what is the difference between parts $a, b, c$ then number 2, what's the difference between options $a, b, c$. numbers 3,4, and 5 Mother, give me 3 minutes..."

Analysis $\quad:$ In Extract 7(2), the lecturer asked students to "distinguish between options a, b, c. number 3, 4, and 5". This type of question is included in the Analysis question (C4) because the distinguishing activity requires analysis, critical or in-depth thinking on options $a, b, c$ in several questions. In addition, the lecturer also uses a pause or pause technique, namely when the question has been submitted, the students are given time to think about the answer so that they have the opportunity to think or analyze the answer and it is hoped that more students will be able to answer and get a complete answer. 


\section{Discussion}

Based on the results described above, the questioning strategies applied by the lecturers are: (1) opening questions; (2) rhetorical questions; (3) managerial questions; (4) knowledge questions; (5) comprehension questions; (6) questions about specific information; (7) analysis questions; (8) use of pausing strategy; (9) the use of prompting strategies; (10) use of probing and prompting strategies; (11) application questions; and (12) closed questions. During the teaching and learning process or the lecture process, lecturers actively ask questions from the beginning to the end of the learning session. This is in accordance with the findings of Boopathiraj \& Chellamani (2013).

Opening Question. Opening questions are used by lecturers to start lectures and check students' readiness to start the teaching and learning process.

Rhetoric Question. Rhetoric questions are questions that actually do not require an answer, but the type of rhetorical question is the most widely used by lecturers in the context of this research. The purposes of using these questions are: (1) used as apperception/introduction/brainstorming at the beginning of the lecture, before entering this material; (2) to direct the flow of thought and invite students to think critically about the material being discussed; (3) reinforce and support the explanation; (4) as a follow-up to previous instructions or to clarify instructions: (5) support inductive explanations, so question words are used sequentially to explain step by step activities in the same time interval; (6) provide a more detailed explanation, for example the presentation of examples.

Managerial Questions. This question is used by lecturers to: (1) prepare students to prepare themselves for each lecture session (starting, core and closing activities; (2) arranging activity transitions or marking the beginning and end of each session; (3) convincing and ensuring students that before moving on to the next session, students have understood the previous activity. This is in accordance with Breen \& Candlin (1987) in Puspa, (2018) that managerial questions are questions that are used to keep the class going.

Knowledge and Memory Questions. In accordance with the Revised Edition of Bloom's Theory in the cognitive domain, operational verbs used by lecturers when submitting knowledge questions (C1) are mentioning, recalling, identifying, and stating. The purpose of using this question is (1) to determine the ability or knowledge of students related to certain information; (2) as an apperception at the beginning of the lecture to connect students' pre-knowledge and the main material to be discussed by asking students to recall or recall previous materials; (3) as reinforcement for the material that has just been delivered; (4) to support material review activities at the end of the lecture.

Understanding Questions (C2). According to Bloom's Revised Edition in the cognitive domain, operational verbs used by lecturers are to explain, give examples, describe, classify. The purposes of using this type of question are: (1) to provide brainstorming to students; (2) knowing the extent to which students understand something. 
Asking Specific Information Regarding Students. This question can be referred to as a filler question or a question to fill the gap to refresh or refresh the class situation and avoid monotonous impression during the presentation of the material. In addition, this question also aims to build emotional closeness between lecturers and students so that they feel cared for.

Analysis Question (C4). Operational verbs used at this level are diagnose, detect, differentiate, select, parse, associate select. The purpose of using this question is to invite students to think critically by analyzing information and finding errors in accordance with the evidence and theories that have been studied.

Use of Pausing Strategy. Pausing technique or strategy aims to provide opportunities for students to answer after the question is submitted. According to Chang (2009), the pausing strategy after the lecturer gives a question aims to provide opportunities to think about answers, get complete answers, understand or analyze questions and provide opportunities for many students to answer.

Use of Prompting Strategy. The purpose of the prompting strategy is to encourage students' understanding of the meaning of the question so that they are able to provide answers that are in accordance with the context of the question by changing the question sentence and adding information to the question sentence so that it is better understood by students.

Combined Use of Probing and Prompting Strategies. The probing strategy applied aims to direct students to achieve answers that are considered complete. However, if the answer given by one student is not complete, then the lecturer adds information to the question sentence and then resubmits it to all students until an answer that is considered complete can be achieved.

Application Question (C3). The operational verbs used by the lecturer at the level of this question are connecting, using, determining. The purpose of using this question is to find out whether students are able to apply the methods and concepts that have been described to solve problems in certain cases.

Closed Questions (Closed Questions). This type of question requires only a limited yes/no answer. The purpose of the lecturer using closed questions is to confirm ongoing student activities and focus students' attention on something. This is in line with the concept of Breen \& Candlin (1987) in Puspa, (2018) that closed questions are used to check retention or to focus thinking on certain points.

Lecturers in the teaching process ask several questions with various objectives: (1) regulate the flow/process from the beginning (apperception) to reinforcement and review at the end of the lecture; (2) provide a stimulus so that students think critically; (2) directing the student's flow of thought to focus on the discussion; (3) giving emphasis, affirmation, examples; (4) knowing the level of understanding of students in the cognitive domain from C1, C2, C3 and C4; (5) build emotional closeness with students; (6) the questions are presented using pausing, prompting and probing techniques to guide 
and direct students to find complete answers and equal opportunities for all students to provide responses.

\section{Conclusion}

Based on the description of the results and discussion, it can be concluded that the questioning strategies applied by the lecturers are: (1) opening questions; (2) rhetorical questions; (3) managerial questions; (4) knowledge questions; (5) comprehension questions; (6) questions about specific information; (7) analysis questions; (8) use of pausing strategy; (9) the use of prompting strategies; (10) use of probing and prompting strategies; (11) application questions; and (12) closed questions.

The purpose of the application of the questions: (1) regulate the flow/process from the beginning (apperception) to reinforcement and review at the end of the lecture; (2) provide a stimulus so that students think critically; (2) directing the student's flow of thought to focus on the discussion; (3) giving emphasis, affirmation, examples; (4) knowing the level of understanding of students in the cognitive domain from C1, C2, C3 and C4; (5) build emotional closeness with students; (6) the questions are presented using pausing, prompting and probing techniques to guide and direct students to find complete answers and equal opportunities for all students to provide responses.

\section{Acknowledgments}

A big thank to the Research and Resources Institute (LP2S) of the Indonesian Muslim University for funding our research activities. We also thank to the lecturers and students who have been willing to participate in this research activities.

\section{References}

Boopathiraj, C., \& Chellamani, K. (2013). Analysis of Test Items on Difficulty Level and Discrimination Index in the Test for Research in Education. International Journal of Social Science \& Interdisciplinary Research, 2(2), 189-193.

Chang, M. (2009). Learning Culture and Language through ICTs : Methods for Enhanced Instruction. London: Information Science Reference.

Cotton, K. (1989). Classroom Questioning. from http://www.nwrel.org/scpd/sirs/3/cu5.html

Halstead, J. M., \& Mclaughlin, T. H. (1999). Education in Morality. London: Routledge

Harmer, J. (2007). The Practice of English Language Teaching (3rd ed.). New York: Longman

Puspa, D. (2018). The Analysis of Questioning Strategies Used By Lecturer In Reading Class. 2nd English Language and Literature International Conference (ELLiC): Vol.2

Hyland, K., \& Paltridge, B. (2011). Continuum Companion to Discourse Analysis. New York: Continuum International Publishing Group. 